\title{
Importance of the Corporate Reputation in B2B Context in Iran:
}

\section{An Empirical Study}

\author{
Dr. Alireza Miremadi (Corresponding author) \\ Marketing Professor \& MBA Director \\ Sharif University of Technology -International Campus, Iran \\ Tel: 98-913-315-2401Ｅ-mail: ar.miremadi@sharif.edu or alireza.miremadi@gmail.com \\ Nazila Babakhani \\ MBA graduated from Sharif University of Technology -International Campus, Iran \\ Tel: 98-912-315-4407Ｅ-mail: nazila_babakhani@yahoo.com \\ Maria Yousefian \\ MBA graduated from Sharif University of Technology -International Campus, Iran \\ Commercial Manager at Beem Company \\ Tel: 98-912-277-9207Ｅ-mail: Maria.yousefian@yahoo.com \\ Hiva Fotoohi \\ MBA graduated from Sharif University of Technology -International Campus, Iran \\ Tel: 98-917-713-9851 E-mail: hivaf_65@yahoo.com
}

Received: June 2, 2011 Accepted: August 31, $2011 \quad$ Published: November 1, 2011

doi:10.5539/ijms.v3n4p146 URL: http://dx.doi.org/10.5539/ijms.v3n4p146

\begin{abstract}
Corporate reputation researches have largely focus on consumer market and attention has been given to the business market recently. The purpose of this paper is to develop an integrated model that indicates the influence of corporate reputation on customer loyalty in Business-to-Business (B2B) markets by implementing the model of Cretu and Brodie (2007) with additional concentration on personal relationship in B2B. To achieve this purpose, a structured questionnaire distributed among 80 executive managers who work in variety industries such as construction, mining and generator motor equipment in Iran. The results prove that corporate reputation has effect on loyalty but with less impact in compared to satisfaction; moreover the personal relation has no significant impact on loyalty.
\end{abstract}

Keywords: B2B market, Corporate reputation, Customer satisfaction, Customer loyalty, Personal relationship, Iran

\section{Introduction}

With the growth of the global competitions, many industries are highly concerned whether corporate reputation can help them to create competitive advantage in such competitive world. The B2B context is a very large and comprehensive sector experiencing growth. Due to the some unique characteristics of this sector such as high transaction costs, achieving customer loyalty and customer satisfaction understanding their antecedent is important which can lead companies to higher profit. It is stated that numerous researchers in marketing have recognized the critical roles of corporate image and corporate reputation in customer's buying behavior (Barich \& Kotler, 1991; Zeithaml, 1981). Corporate reputation is likely to have an important influence on the buying processes that is different from brand's image which focus on specific product category (Mudambi, 2002), so corporate reputation plays fundamental role in developing and maintaining customer loyalty. 
The purpose of this paper consequently is to develop a model that account for the influence of corporate reputation on loyalty and examine the role of personal relationship on business loyalty in an extended model of Cretu and Brodie (2007).

The paper begins by examining the marketing literature on corporate reputation, customer satisfaction and customer loyalty, perceived quality, price and personal relationship. Drawing from the literature, a model (Figure 1 ) is introduced, and hypotheses are developed. In next section methodology is presented and then the results are discussed. Finally, paper concludes, discuss the limitations and offer recommendation for future research.

\section{Literature review and framework}

In developing our model we reviewed the literature on satisfaction, quality, company reputation, price, personal relationship and customer loyalty. On the basis of this review we define the constructs of our framework and describe the theoretical evidence, which support the relationships in this model. Below is a brief discussion about the relationships.

\subsection{Customer satisfaction and loyalty}

Customer loyalty is almost the customer intention for taking repurchase action and their willingness to provide positive word of mouth (Andreassen \& Lindestad, 1998). Loyalty has been extensively investigated in relation to customer satisfaction. Milonari, Abratt \& Dion (2008) found a positive relation between satisfactions and repurchase. Also many scholars examined the direct impact of customer satisfaction on customer loyalty. (Anderson, Fornell, \& Lehmann, 1994; Eggertt \& Ulga, 2002; Lam, Shankar, Erramilli, \& Murthy, 2004; Patterson \& Spreng, 1997; Zins, 2001). On the other hand, (helm, 2007) suggested that although many researchers had found the direct and significant relation between satisfaction and loyalty, satisfaction is not always the only and reliable antecede of loyalty. In this study the authors wish to examine the relation existed between both constructs in B2B context.

H1: Customer satisfaction has a positive impact on customer loyalty.

\subsection{Corporate reputation, satisfaction and loyalty}

Otubanjo and Chen (2011) defined corporate reputation as a functional phenomenon arising from the creation of a variety of valuable attributes, which differentiate firms, foster relationships, and makes business organizations famous over time through the formal and informal lines of corporate communications. In B2B, Suh \& Houston (2010) found that supplier reputation is a significant and positive antecedent to a buyer's effective commitment to a relationship and to that buyer's willingness to invest in the future of the relationship. Several scholars examined the differences between Corporate reputation and Brand images for example, Cretu \& Brodie (2007) investigated difference between corporate reputation and brand's image which is associated with a specific product category, on buying decision by testing influences of brand image and corporate reputation on customers' perceptions of product and service quality, customer value, and customer loyalty in a business market. They concluded that the brand's image has a more specific influence on the customers' perceptions of product and service quality, while corporate reputation has a broader impact on perceptions of customer value and customer loyalty.

Nguyen \& Leblanc (2001) stated that corporate reputation and corporate image are acknowledged as having the potential to impact on customer loyalty toward the firm. Andreassen \& Lindestad (1998) believed that corporate image as a part of corporate reputation can lead to customer loyalty, moreover, Anderson et al., (1994); Ryan, Rayner, \& Morrison (1999) found that reputation is the strong factor that has significant impact on loyalty. Ostrowski, O'Brien, \& Gordon (1993) argued "The consumer may consider a bad experience as an exception to his whole impression of the service provider". In addition, this study suggested a consistent and significant relationship between the reputation and customer loyalty. Empirical research that links the effect of corporate reputation to loyalty includes studies by (Anderson, et al., 1994; Cretu \& Brodie, 2007; Raj, 1985; Roberts \& Dowling, 2002; Ryan, et al., 1999; Zins, 2001). In this study the authors will examine the direct impact of corporate reputation on customer loyalty.

Corporate reputation is a broad construct and hence it is assumed to have a strong influence on the customer satisfaction. Bontis \& Booker (2007) believed that the link between satisfaction and reputation gain less attention in compare to the link between loyalty and reputation. Henning-Thurau, Gwinner, \& Gremler (2002)demonstrated that "customers who are satisfied with the performance of a company are more likely to engage in positive word-of-mouth, thus positively reinforcing the corporate reputation". There are some studies that examined the relation between satisfaction and reputation and found that satisfaction leads to reputation. (Anderson \& Sullivan, 1993; Bontis \& Booker, 2007). Also there are other empirical researches that have 
demonstrated a positive influence of corporate reputation on customer's satisfaction (Anderson, et al., 1994; Davies, Chun, Silva, \& Roper, 2002).

H2: Corporate Reputation has a positive impact on customer satisfaction.

H3: Corporate Reputation has a positive impact on customer loyalty.

\subsection{Product quality, satisfaction and reputation}

According to Andreassen \& Lindestad (1998), perceived quality is defined as customer general opinion about the specific product or service superiority. Rauyrun \& Miller (2007) found the relationships between service quality and loyalty through satisfaction and stated that there is a need to understand the relationship in B2B market. Yi (1989) stated that customer satisfaction is a function of perceived (service) quality and expectations. There are arguments that service quality is influenced by customer satisfaction (Bitner \&Hubbert, 1994) or customer satisfaction is effected by self-evaluation of the customer on quality or service (Anderson \& Sullivan, 1993; Cretu \& Brodie, 2007; Fornell, 1992; Tse \& Wilton, 1988). In this study satisfaction is modeled to be under the influence of perceived quality.

Furthermore, there are some researchers, which investigated the impact of quality on corporate reputation. Shapiro (1983) claimed that reputation is determined by the quality of the product consumed in the previous period, while Tirole (1996) found that past average quality of firm lead to a common reputation and recently Winfree \& McCluskey (2005) asserted that reputation is an incentive for firms to produce high quality product or services. In this study the impact of quality on two constructs of corporate reputation and customer satisfaction will be examined.

H4: Perceived quality has a positive impact on corporate reputation.

H5: Perceived quality has a positive impact on customer satisfaction.

\subsection{Price and satisfaction}

According to (Voss, Parasuraman, \& Grewal, 1998) the effect of price on satisfaction has received considerably less research attention than other satisfaction antecedents. Jiang \& Rosenbloom (2005) supported a positive relation between customer price perception and customer satisfaction. On the other hand, Varki \& Colgate (2001) examined the relation of price perception on customer satisfaction and found price perception on comparative basis, have strong, significant impact on customer satisfaction and behavioral intention. In this research the direct impact of price on customer satisfaction will be conducted. Voss et al., (1998) argued that satisfaction is a function of price, performance and expectations. They propose that perceived price might be the dominant determinant of satisfaction. Herrmann A. \& Xia L. \& Monroe K. \& Huber F. (2007) proposed that Price is an important element in consumers' purchases; therefore it has a large influence on consumers' satisfaction judgments. Price perceptions influence consumers' overall satisfaction judgments directly and indirectly through price fairness perceptions. Bolton and Lemon (1999) stated that satisfaction typically mediates the effects of product price or payment equity on loyalty.

H6: Price has a positive impact on customer satisfaction.

\subsection{Personal relationships and loyalty}

According to Iacobucci and Ostrom, (1996) relationships at the structural level are firm-to-firm, individual-to-individual and individual-to-firm relationships. In this paper the focus of our attention is on either firm-to-firm or individual to firm relationships. Price \& Arnould (1999) believed that as the personal interaction continues over time, social bonds are likely to develop between the parties. Thus such bonds are important to gain customer loyalty, and the social aspects of a relationship are sometimes found to be even more important than occasional price breaks or special service (Gwinner, Gremler, \& Bitner, 1998). Selnes \& Hansen (2001) stated that the antecedent of customer loyalty gain attention of the researchers and interestingly in their study they claimed that personal relationship have been identified as a potential driver of loyalty. Foster \& Cadogan (2000) stated "buyers are not necessarily committed to establishing long- term relationships with their suppliers; rather, it is suppliers themselves who are proactive in the development of marketing relationships since they see a resulting economic benefit as a direct result of customers' loyalty behaviors". Yau et al., (1999) pointed out in the context of business-to-business industrial relationships, "relationships require strong elements of interpersonal obligation, and are undertaken between individuals or networks of individuals rather than between organized corporate groups". Butcher et al., (2001) asserted that closeness of interpersonal friendship relationships with the service provider are potential antecedent of customer loyalty towards the firm. Guenzi \& Pelloni (2004) findings revealed that customer-to-employee and customer-to-customer relationships contribute in 
a very different manner to the development of the customer-to-firm relationship in the context of social-intensive consumer services. Their results show that customer-to-employee relationship closeness presents a stronger link with personal intentional loyalty than with intentional loyalty to the firm. It is highly investigated that the personal relationships between the customer and the salesperson will highly influence the firm-selling outcome on account of its impact on customer satisfaction and trust as well as repurchase intentions, willingness to recommend the provider to other potential customers (Foster and Cadogan, 2000; Tam and Wong, 2001; Johnson et al. 2003). On the other hand, Bov \& Johnson (2000) and Caldow et al., (2000) pointed out that in case the service employee leaves the company, the existence of a customer-to-employee relationship and the creation of a personal loyalty to a specific firm's person could contribute negatively to customer loyalty to the firm, and hence to customer-to-firm relationship.

H7: Personal relationship has a positive impact on customer loyalty.

\section{Methodology}

\subsection{Sampling}

Descriptive study are often used to test hypotheses, and data collection involves ask structured question (Hair et al., 2007). Cross-sectional descriptive studies are considered as providing a snapshot or description of business elements at a given point in time. Hair et al., (2007) state that since population characteristics are being inferred from a sample, or subset of the population, cross-sectional descriptive studies must carefully consider how well the selected subset represents the larger population.

Furthermore, Hair et al., (2007) suggest that when pragmatic reasons, such as budget and time constraints, existed alternative ad hoc methods can be used including: previous similar studies, one's own experience or simply dictated by what is affordable. With regard to the fact that researchers applied Non- probability sample method, however the researcher distributed 80 questionnaires among various industrial sectors such as construction, mining and generator equipment in Iran.

\subsection{Data collection}

Primary data is collected through structured questionnaire, which is administered between executive managers of mentioned companies. The managers are asked about their opinion about suppliers based on their last purchase experience.

\subsection{Sample characteristics}

The sample was mainly male (57.5 percent), and majority of respondents ranged from 20 to 35 years old who has mostly Bachelor's degree (See Table 1).

\subsection{Measures development}

The questionnaire finally consisted of seventeen statements and the executive manager respondents were asked to indicate the degree of agreement with these on a five point scale $(1=$ completely disagree/completely negative/completely low), $(5$ = completely disagree/completely negative/completely low $))$. It was administrated to 80 executive mangers to measure corporate reputation.

With referred to Table 2, shows items evaluating the model construct: corporate image (6 items), perceived product/service quality ( 3 items), price ( 2 items), customer satisfaction ( 3 items), customer loyalty ( 2 items) and finally personal relationship $(1 \mathrm{item})$. All latent variables are conceptualized with different manifest variables based on literatures review. Corporate reputation is measured according to the criteria of Cretu \& Brodie (2007), however since the industry in this research is different from our context, the measures are modified to ensure that items are relevant to the targeted industry. For perceived quality of product/service and price the measures are selected based on the Cretu \& Brodie, (2007) with some minor modifications the same as before. Customer satisfaction items are drawn from American Customer Satisfaction (ACSI) model (Fornell, Johnson, Anderson, Cha, \& Bryant, 1996). Customer loyalty manifests itself through two main items based on lam et al., (2004). Finally, Due to the lack of literature on personal relationship this construct is operational zed by one item, which evaluates this construct in general.

In order to modeling relationships between latent variables, principally two different methodological approaches are existed: on one hand covariance structure analysis (programs like LISREL or AMOS) and on the other hand PLS path modeling (programs like PLS-Graph, Smart PLS, or SPAD-PLS) (Temme et al., 2006). In recent years there is a growing interest among researchers in applying the PLS path modeling approach (Ulaga \& Eggert, 2006a \&b; Hutchinson et al., 2010; Alejandro et al., 2010). This is because there are specific identification problems in modeling so-called formative constructs by using covariance structure analysis, which are not an 
issue in PLS (Temme et al., 2006). - PLS provides an iterative combination of principal components analysis that relates measures to constructs and path analysis that captures the structural model of constructs (Wagner et al. 2010). We selected PLS program for a few reasons such as ease of use, adaptability, and consistency with analytical approach of Ulaga \& Eggert (2006a \&b) and Hutchinson et al., (2010).

\section{Results}

\subsection{Measurement model}

A questionnaire is considered reliable if its repeated application results in consistent scores (Hair et al., 2007). According to Hair et al., (2007) reliability is most often associated with multi-items scales. Construct's reliability is assessed by calculating the correlation among individual items that represents a construct (Hair et al., 2007). Internal consistency reliability is used to assess a summated scale where several statements (items) are summed to form a total score for a construct (Hair et al., 2007). Most researchers accept Cronbach`s alpha greater than 0.7. In the present study internal consistency reliability coefficient alpha is employed to ensure the reliability of the survey instrument. Moreover, establishing the content or face validity of a scale involve a systematic but subjective assessment of a scale's ability to measure what is supposed to measure (Hair et al., 2007). Consulting with a small sample of respondents and experts, to make judgment on the suitability of the indicators chosen to represent the construct, are used to guarantee content validity (Hair et al., 2007). All of these conditions are met in developing our survey instrument.

The respective measures of all constructs have acceptable internal consistency reliability presenting composite reliability above 0.7 , also individual item reliability is assessed by examining the loading of the manifest variables with their respective construct which should be greater than 0.70 (Henseler, Ringle, \& Sinkovics, 2009). This condition can be met in our research except loading of CR4, CR5, and PR1, which are 0.67, 0.64 and 0.5053 (Table 3). Convergent validity is obtained by average variance extracted (AVE) that is suggested, at least, higher than .5 (Fornell, 1992). The average communality scores of company reputation, perceived quality of product/ service, price, customer satisfaction and customer loyalty are acceptable (Table 4).

This study assesses discriminate validity using the Fornell-Larcker criterion (Fornell \& Larcker, 1981), which requires a latent variable to share more variance with its assigned indicators than with any other latent variable. Based on this criterion the square root of the variance extracted should be larger than the corresponding inter-construct correlations (Hulland, 1999). This condition is met in all cases (see Table 4).

\subsection{Model and hypotheses test}

The results of the partial least squares (Smart PLS 2.0) analysis are summarized in Figure 1. The path coefficients $(\beta)$ and variance $\left(R^{2}\right)$ are shown. The results indicate that in the model relatively large amount of variance is explained for loyalty $\left(\mathrm{R}^{2}=0.54\right)$ and satisfaction $\left(\mathrm{R}^{2}=0.57\right)$ constructs. In addition, the researcher should test for statistical significance of path coefficient. The significance level of coefficients can be computed using a bootstrap re-sampling procedure to obtain a t-statistic which is generated by the PLS program (Chatelin, Vinzi, \& Tenenhaus, 2002).

With respect to our statistical analysis, loyalty construct mainly depends on customer satisfaction (.529) however; corporate reputation has less important effect on it (.256). Regression relationship for customer satisfaction shows that product/service quality and price have a significant impact on customer satisfaction $(0.367,0.293)$. As it is hypothesized, corporate reputation can be predicted by product/ service quality ( 0.559$)$. Finally, it should be noted that in our model personal relationship shows no significant impact on loyalty $(0.027)$

It is found that, all the hypothesis structural paths among the independent constructs and dependent constructs in the final model are accepted, except $\mathrm{H} 7$ which states personal relationship, has positive impact on customer loyalty and are significant according to the t-statistic values.

\section{Conclusion}

Corporate reputation is considered as vital asset to increase a company's financial performance and permanent competitive advantage in many B2B in Iran, who try to capture the best unique selling proposition for their company image and products. The aim of this study is to find out the role of corporate reputation on customer loyalty in B2B context in B2B in Iran. Although the impact of corporate reputation is stated by many studies (Andreassen \& Lindestad, 1997, 1998; O'Loughlin \& Coenders, 2002), limited research investigates the importance of corporate reputation in $\mathrm{B} 2 \mathrm{~B}$, therefore discovered variable in the extended model can be contribution of this study. The basis of our model is the previous research by Cretu \& Brodie (2007). The invert path from product and service quality to corporate image is incorporated in this model, customer value is replaced with customer satisfaction and personal relationship construct is included. It is investigated whether 
growing personal relationship between a business buyer and a supplier might account for supplier choices in detail. This study reconfirmed the importance of previous scholars' works. Firstly, it is found that reputation has significant impact on business loyalty, however, reputation has less impact and satisfaction is considered as main predictor of loyalty. Secondly, it is concluded that reputation of the supplier can be influenced by product and service quality. Finally, price and perceived product /service quality has a direct impact on customer satisfaction.

\subsection{Managerial implication}

According to the results of this study, it is essential for mangers to understand how customers perceived their company; furthermore managers should take into consideration the essential factors that convert the customer to loyal customer in B2B scenario in Iran. Furthermore customer satisfaction and loyalty act as versatile weapon for marketing strategies of product and service.

As it is proven, the perception of the customer on specific firm highly depends on how they perceive the competitor products or service in the market, thus managers must recognize variety ways to create added value and understand the power of external influences on customer perceptions as well as their corporate reputation. Moreover, the positive impact of quality on customer satisfaction and corporate reputation creates essential implications for managers to capture the market with superior product or services in B2B context.

By understanding the significant impact of price on customer satisfaction and in turn on customer loyalty that had been proved in this study, it is considered as strength signal for managers to opt a technical pricing strategy for their product, furthermore it is an established fact that there should be an investment by the firms to achieve high quality product and corporate reputations, which in consequence lead to higher price, managerial implication is to explore financial implications and tradeoffs in investing product quality and corporate reputations versus product pricing (Cretu and Brodie, 2007).

\section{Limitation and future research}

Lack of sufficient relevant Iranian literature review found to be main constrain in this research, therefore researchers could only consider one measurement for personal relationship construct, which lead slack of support for the hypotheses that examined personal relationship's impact on loyalty, thus more precise measurements for significantly examining the personal relation is needed in future in B2B markets as we recognize in other circumstance there may be support for it, in other word, further research is needed to determine the best way to develop a scale to measure personal relationship. Also during the data collection, accessibility of data for having large sample size is accompanied with some difficulties due to the low knowledge of managers about the concept of customer loyalty or their low cooperation on the research thus the total sample size of $(n=80)$ is another considerable limitation of this research. In this study data are achieved from limited business companies, which makes the results bias on account of cultural aspect, so future research is recommended for acquiring data from different companies to demonstrate different organization culture in order to generalize the results. Finally, our study focuses on an established industrial market and results may be different for markets of other sectors.

\section{References}

Alejandro, T., Souza, D., Boles, J., Ribeiro, A., \& Monteiro, P. (2010). The outcome of company and account manager relationship quality on loyalty, relationship value and performance. Industrial Marketing Management.

Anderson, E. W., Fornell, C., \& Lehmann, D. R. (1994). Customer satisfaction, market share, and profitability findings from Sweden. Journal of marketing, 58(3), 53-66.

Anderson, E. W., \& Sullivan, M. W. (1993). The antecedents and consequences of customer satisfaction for firms. Marketing Science, 12 (2).

Andreassen, T. W., \& Lindestad, B. (1997). Customer Loyalty and Complex Services, the Impact of Corporate Image on Quality,Customer Satisfaction and Loyalty for Customers with Varying Degrees of Service Expertise. International Journal of Service Industry Management, 4, 1-33.

Andreassen, T. W., \& Lindestad, B. (1998). Customer loyalty and complex services: The impact of corporate image on quality, customer satisfaction and loyalty for customers with varying degrees of service expertise. International Journal of Service Industry Management, 9(1), 7-23.

Barich, H., \& Kotler, P. (1991). A framework for marketing image management. Sloan Management Review, 32(2), 94-104.

Bitner, M. J., \& Hubbert, A. R. (1994). Encounter satisfaction versus overall satisfaction versus quality: the customer's voice. 
Bolton R., \& Katherine N. Lemon. (1999). A Dynamic Model of Customers' Usage of Services: Usage as an Antecedent and Consequence of Satisfaction. Journal of Marketing Research, 36 (May), 171-86.

Bontis, N., \& Booker, L. D. (2007). The mediating effect of organizational reputation on customer loyalty and service recommendation in the banking industry. Management Decision, 45(9), 1426-1445.

Bove, L. L., and Johnson, L.W. (2000). A customer-service worker relationship model International Journal of Service Industry Management, Vol. 11, No. 5, pp. 491-511.

Butcher, K., Sparks, B., and O'Callaghan, F. (2001). Evaluative and relational influences on service loyalty. International Journal of Service Industry Management, Vol. 12, No. 4, pp. 310-27.

Caldow, D., Patterson, P., and Uncles, M. (2000). The impact of friendship between consumers and service-providers on loyalty to the service firm. Paper presented at ANZMAC 2000: Visionary Marketing for the 21th Century: Facing the Challenge. [Online] Available: http://www.anzmac.org/

Chatelin, Y. M., Vinzi, V. E., \& Tenenhaus, M. (2002). State-of-Art on PLS Path Modeling through the Available Software.

Cretu, A. E., \& Brodie, R. J. (2007). The influence of brand image and company reputation where manufacturers market to small firms: A customer value perspective. Industrial Marketing Management, 36, 230-240.

Davies, G., Chun, R., Silva, R. V. D., \& Roper, S. (2002). Corporate Reputation and Competitiveness,.

Eggertt, A., \& Ulga, W. (2002). Customer perceived value: A substitute for satisfaction in a business market. Journal of Business and Industrial Marketing , 17(2/3), 107-118.

Fornell, C. (1992). A national customer satisfaction barometer: the Swedish experience. Journal of marketing, 56(1), 6-21.

Fornell, C., Johnson, M. D., Anderson, E. W., Cha, J., \& Bryant, B. E. (1996). The American customer satisfaction index: nature, purpose and findings. Journal of Marketing, 60(4), 7-18.

Fornell, C., \& Larcker, D. F. (1981). Structural equation models with unobservable variables and measurement error: Algebra and statistics. Journal of Marketing Research, 18(3), 328-388.

Foster, B. D., \& Cadogan, J. W. (2000). Relationship selling and customer loyalty: an empirical investigation. Marketing Intelligence \& Planning, 18(4), 185-199.

George, W.R. (1981). Marketing of Services. American Marketing Association, Chicago, pp. 186-190.

Gustafsson A., \& Johnson M., \& Roos I. (2005). The Effects of Customer Satisfaction, Relationship Commitment Dimensions, and Triggers on Customer Retention. Journal of Marketing,Vol. 69, 210-218.

Gwinner, K., Gremler, D., \& Bitner, M. J. (1998). Relational Benefits in Service Industries: The Customer's Perspective. Journal of the Academy of Marketing Science, 26(2), 101-114.

Hair, JF., Money, A., Samouel, P., \& Page, M. (2007). Research method for business. John Wiley \& Sons, Ltd.

helm, S. (2007). The Role of Corporate Reputation in Determining Investor Satisfaction and Loyalty. Corporate Reputation Review, 10(1), 22-37.

Hennig-Thurau, T., Gwinner, K. P., \& Gremler, D. D. (2002). Understanding relationship marketing outcomes: an integration of relational benefits and relationship quality. Journal of Service Research, 5, 230-247.

Henseler, J., Ringle, C. R., \& Sinkovics, R. R. (2009). The use of partial least squares path modeling in international marketing. Advances in International Marketing, 20, 227-319.

Herrmann A., Xia L., Monroe K., \& Huber F. (2007). The influence of price fairness on customer satisfaction: an empirical test in the context of automobile purchases. Journal of Product \& Brand Management, 16/1 pp.49-58.

Hulland, J. S. (1999). Use of partial least squares (PLS) in strategic management research: A review of four recent studies. Strategic Management Journal, 20(4), 195-204.

Hutchinson, D., Wellington, W., Saad, M., \& Cox, P. (2010). Refining value-based differentiation in business relationships: A study of the higher order relationship building blocks that influence behavioral intentions. Industrial Marketing Management.

Iacobucci, D., and Ostrom, A. (1996), Commercial and interpersonal relationship: using the structure of interpersonal relationship to understand individual-to-individual, individual-to-firm and firm-to-firm relationships in commerce. International Journal of Research in Marketing, Vol. 13, pp. 53-72. 
Jiang, P., \& Rosenbloom, B. (2005). Customer intention to return online: price perception, attribute-level performance, and satisfaction unfolding over time. European Journal of Marketing, 39(1/2), 150-174.

Johnson, J.T., Barksdale, H.C., and Boles, J.S. (2003). Factors associated with customer willingness to refer leads to salespeople. Journal of Business Research, Vol. 56, pp. 257-63.

Lam, S. Y., Shankar, V., Erramilli, M. K., \& Murthy, B. (2004). Customer value, satisfaction, loyalty, and switching costs: an illustration from a business-to-business service context. Journal of the Academy of Marketing Science, 32, 293-311.

Milonari, L. K., Abratt, R., \& Dion, P. (2008). Satisfaction, quality and value and effects on repurchase and positive word-of-mouth behavioral intentions in a B2B services context. Journal of service marketing, 22(5), 363-373.

Mudambi, S. (2002). Branding importance in business-to-business markets Three buyer clusters. Industrial Marketing Management, 31, 525-533.

Nguyen, N., \& Leblanc, G. (2001). Corporate image and corporate reputation in customers' retention decision in services. Journal of Retailing and Con- sumer Services, 8, 227-236.

O'Loughlin, C., \& Coenders, G. (2002). Application of the European Customer Satisfaction Index to Postal Services. Structural Equation Models versus Partial Least Squares. University of Girona.

Ostrowski, P. L., O'Brien, T. V., \& Gordon, G. L. (1993). Service quality and customer loyalty in the commercial airline industry. Journal of Travel Research, 32(2), 16-24.

Otubanjo, O., \& Chen, C.-C. (2011). The Meaning of Corporate Reputation: A Functional and Semiological Analysis.

Patterson, P. G., \& Spreng, R. A. (1997). Modelling the relationship between perceived value, satisfaction and repurchase intentions in a business-to- business, services context: An empirical examination. International Journal of Service Industry Management, 8(5).

Price, L. L., \& Arnould, E. J. (1999). Commercial Friendships: Service-Provider-Client Relationships in Context. Journal of marketing, 63, 38-56.

Raj, S. P. (1985). Striking a balance between brand "popularity" and brand loyalty. Journal of marketing, 49(1), 53-59.

Rauyruen, P., \& Miller, K. E. (2007). Relationship quality as a predictor of B2B customer loyalty. Journal of Business Research, 60, 21-31.

Roberts, P. W., \& Dowling, G. R. (2002). Corporate Reputation and Sustained Superior Financial Performance. Strategic Management Journal, 23, 1077-1093.

Ryan, M. J., Rayner, R., \& Morrison, A. (1999). Diagnosing customer loyalty drivers. Marketing Research, 11(2), 18-26.

Selnes, F., \& Hansen, H. V. (2001). The Potential Hazard of Self-Service in Developing Customer Loyalty. Journal of Service Research, 4(2), 79-90.

Shapiro, C. (1983). Premiums for high quality products as returns to reputations. Quarterly Journal of Economics, 98, 659-679.

Suh, T., \& Houston, M. B. (2010). Distinguishing supplier reputation from trust in buyer supplier relationships. Industrial Marketing Management, 39, 744-751.

Tam, J.L.M., and Wong, Y.H. (2001). Interactive selling: a dynamic framework for services. Journal of Services Marketing, Vol. 15 No. 2, pp. 379-96.

Temme, D. Kreis, H. Hildebrandt, L. (2006). PLS path modeling - A software review. SFB 649 discussion paper.

Thompson, R., Barclay, D. W., \& Higgins, C. A. (1995). The partial least square approach to causal modeling: personal computer adoption and use as illustration, 284-324.

Tirole, J. (1996). A theory of collective reputations( ith applications to the persisitance of corruption and to firm quality). The quarterly journal of economics, 98(4), 659-680.

Tse, D. K., \& Wilton, P. C. (1988). Models of Consumer Satisfac- tionFormation: An Extension. Journal of Marketing Research, 204-212. 
Ulaga, W., and Eggert, A. (2006b). Relationship value and relationship quality: broadening the nomological network of business-to-business relationships. European Journal of Marketing, Vol. 40, No. 3/4, pp. 311-27.

Ulaga, W., and Eggert, A. (2006a). Value-based differentiation in business relationships: gaining and sustaining key supplier status. Journal of Marketing, Vol. 70, No. 1, pp. 119-36.

Varki, S., \& Colgate, M. (2001). The role of price perceptions in an integrated model of behavioral intentions. Journal of Service Research, 3(3), 232.

Voss, G. B., Parasuraman, A., \& Grewal, D. (1998). The Roles of Price, Performance, and Expectations in Determining Satisfaction in Service Exchanges. Journal of marketing, 62, 46-61.

Wagner, S., Eggert, A., \& Lindemann, E. (2010). Creating and appropriating value in collaborative relationships. Journal of Business Research, 63 (2010), 840-848.

Winfree, J. A., \& McCluskey, J. J. (2005). Collective Reputation and Quality. American Journal of Agricultural Economics, 87(1), 206-213.

Yau, O.H.M., McFetridge, P.R., Chow, R.P.M., Lee, J.S.Y., Sin, L.Y.M., and Tse, A.C.B. (1999). Is relationship marketing for everyone? European Journal of Marketing, Vol. 34 No. 9/10, pp. 1111-27.

Yi, Y. (1989). A Critical Review of Customer Satisfaction, in Zeithaml. American Marketing Association, 68-123.

Zeithaml, V.A. (1981). How consumer evaluation processes differ between goods and services. Journal of Service Marketing. In: Donnelly, J.H.

Zins, A. H. (2001). Relative attitudes and commitment in customer loyalty models: Some experiences in the commercial airline industry. International Journal of Service Industry Management, 12(3/4), 269-294.

Table 1. Qualitative data

\begin{tabular}{|l|lc|}
\hline Demographic characteristics $(\mathbf{n}=\mathbf{8 0})$ & \% Response & \\
\hline Gender & Male & 57.5 \\
& Female & 42.5 \\
\hline Age & $<20$ & 2.5 \\
& $20-35$ & 50 \\
& $35-50$ & 25 \\
& $>5022.5$ & \\
\hline Education & Diploma & 13.8 \\
& Bachelor & 50 \\
& Master & 30 \\
& PHD & 6.2 \\
\hline
\end{tabular}


Table 2. Measurement items included in questionnaire

\begin{tabular}{|l|l|}
\hline Latent variable & Manifest variable \\
\hline Corporate image & 1) Having a reputation for quality \\
& 2) Being well known \\
& 3) Having good experience \\
& 4) Being well managed \\
& 5) Having customer focus \\
& 6) Being successful \\
\hline Perceived product and service quality & 1) Overall products and service quality \\
& 2) The training that they offer you, \\
& 3) Order handling and delivery, \\
\hline Price & 1) Prices in comparison to other companies, \\
& 4) Value relative to the price \\
\hline Customer satisfaction & 1) Overall satisfaction with the products and services \\
& 2) Performance versus the customer's ideal product or \\
& service in the category \\
& 3) Considering expectation, fulfill expectations \\
\hline Customer loyalty & 1) Likelihood of repurchase in future \\
& 2) The likelihood to recommend the company to the \\
& other colleagues \\
\hline Personal relationship & 1) Having long term relationship \\
\hline
\end{tabular}

Table 3. Properties of measurement model

\begin{tabular}{|c|c|c|c|c|}
\hline Factor/indicator & Loading & t-values & $\begin{array}{l}\text { Composite } \\
\text { Reliability }\end{array}$ & $\begin{array}{c}\text { Cronbach's } \\
\text { Alpha }\end{array}$ \\
\hline Corporate reputation (CR) & & & 0.8886 & 0.8479 \\
\hline CR1 & 0.8266 & 18.94 & & \\
\hline CR2 & 0.7299 & 11.31 & & \\
\hline CR3 & 0.8332 & 29.04 & & \\
\hline CR4 & 0.6793 & 12.169 & & \\
\hline CR5 & 0.6484 & 10.505 & & \\
\hline CR6 & 0.8037 & 20.673 & & \\
\hline $\begin{array}{l}\text { Product and service quality } \\
\text { (PSQ) }\end{array}$ & 0.8238 & & 0.7788 & 0.6123 \\
\hline PSQ1 & 0.8435 & 18.964 & & \\
\hline PSQ2 & 0.8120 & 5.42 & & \\
\hline PSQ3 & 0.7386 & 11.594 & & \\
\hline Price (PR) & & & 0.7255 & 0.4077 \\
\hline PR1 & 0.5053 & 2.99 & & \\
\hline PR4 & 0.9636 & 36.710 & & \\
\hline Satisfaction (SAT) & & & 0.8856 & 0.8061 \\
\hline SAT1 & 0.8657 & 31.540 & & \\
\hline SAT2 & 0.8583 & 31.565 & & \\
\hline SAT3 & 0.8223 & 23.751 & & \\
\hline Personal relationship (PER) & & 55.987 & 1 & 1 \\
\hline PER & 1 & 0 & & \\
\hline Customer Loyalty (LOY) & & & 0.8457 & 0.6377 \\
\hline LOY1 & 0.8817 & 37.662 & & \\
\hline LOY2 & 0.8297 & 15.781 & & \\
\hline
\end{tabular}


Table 4. Convergent and discriminate validity

\begin{tabular}{|l|c|c|c|c|c|c|c|}
\hline & AVE & $\begin{array}{c}\text { Corporate } \\
\text { reputation }\end{array}$ & Satisfaction & Price & Loyalty & $\begin{array}{c}\text { Personal } \\
\text { relationship }\end{array}$ & $\begin{array}{c}\text { Product } \\
\text { and } \\
\text { service } \\
\text { quality }\end{array}$ \\
\hline $\begin{array}{l}\text { Corporate } \\
\text { reputation }\end{array}$ & 0.5730 & $\mathbf{0 . 7 5 6 9}$ & & & & & \\
\hline Satisfaction & 0.7207 & 0.6169 & $\mathbf{0 . 8 4 8 9}$ & & & & \\
\hline Price & 0.5919 & 0.4007 & 0.5366 & $\mathbf{0 . 7 6 9 3}$ & & & \\
\hline Loyalty & 0.7329 & 0.5894 & 0.6934 & 0.3216 & $\mathbf{0 . 8 5 6 0}$ & & \\
\hline $\begin{array}{l}\text { Personal } \\
\text { relationship }\end{array}$ & 1 & 0.2493 & 0.2307 & -0.0294 & 0.2132 & $\mathbf{1}$ & \\
\hline Quality & 0.5919 & 0.5586 & 0.632 & 0.3425 & 0.5928 & 0.0486 & $\mathbf{0 . 7 4 9 5}$ \\
\hline
\end{tabular}

Note: Diagonal elements are the square root of the average variance extracted (AVE) between the constructs and their measures. The off-diagonal elements are correlation between the constructs.

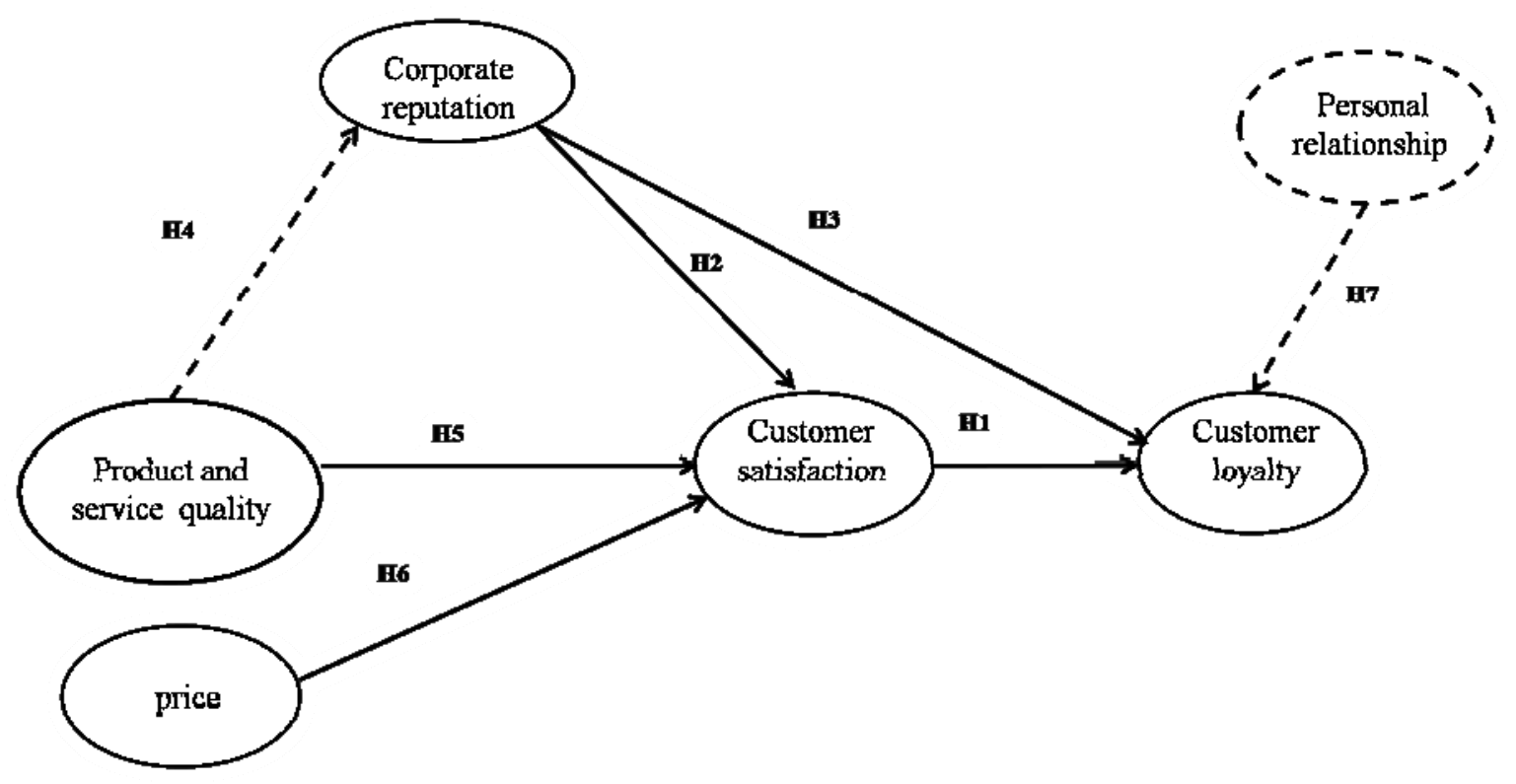

Figure 1. Model and hypothesizes 


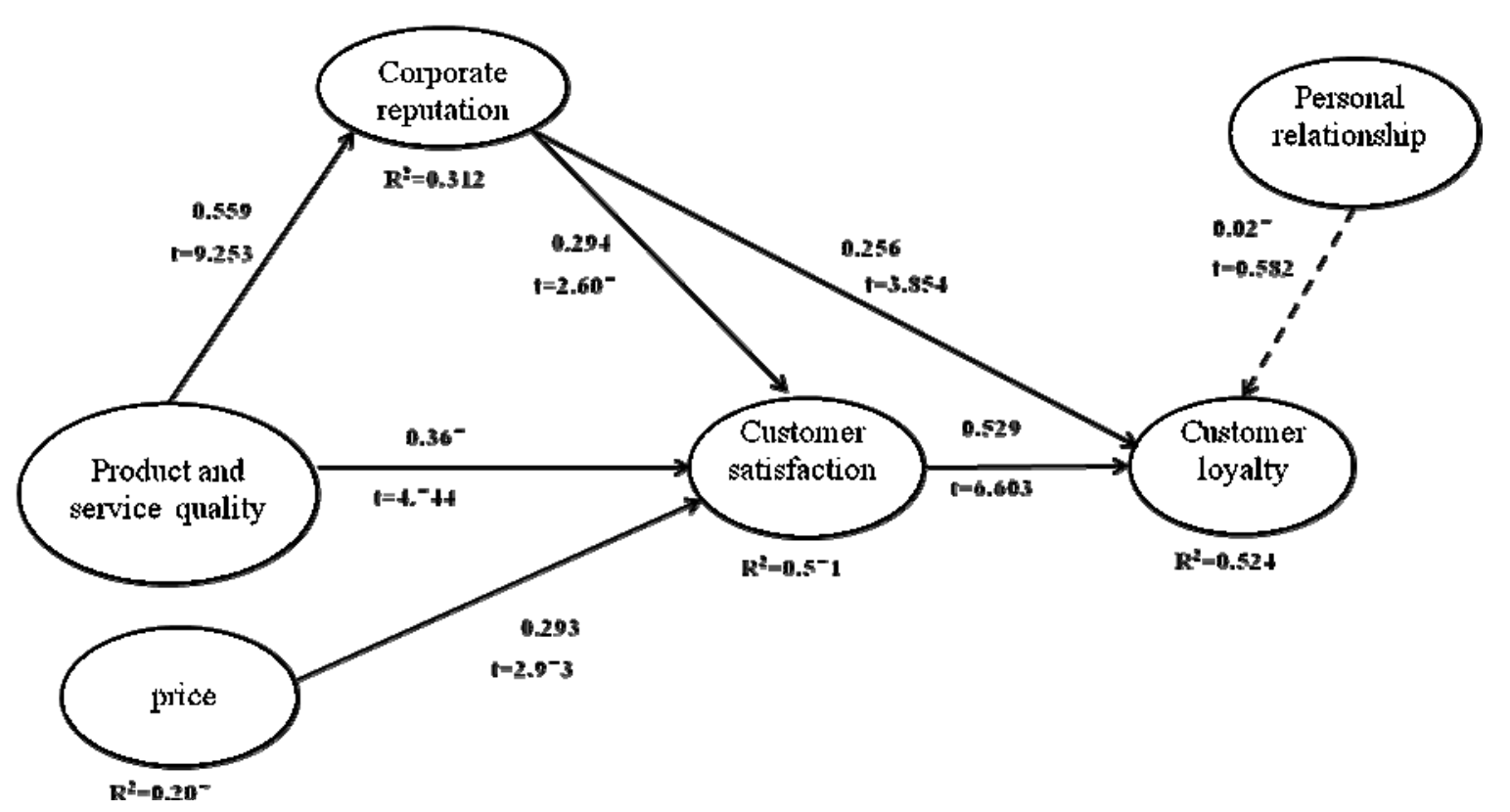

Figure 2. Standardized estimates and t-values. (Standardized estimates with t-values, at $\mathrm{p}<0.10$ ) 